International Journal of Linguistics, Literature and Culture
Available online at https://sloap.org/journals/index.php/ijllc/
Vol. 4, No. 6, November 2018, pages: $28 \sim 41$
ISSN: $2455-8028$
https://sloap.org/journals/index.php/ijllc/article/view/339

\title{
The Fulfillment of the Biblical Statement "Vanity of vanities! All is vanity" through the Portrayal of Two Characters in Armah's The Beautyful Ones Are Not Yet Born
}

Article history:

Received: 20 June 2018

Accepted: 30 August 2018

Published: 6 November 2018

\section{Keywords:}

Modest;

Power;

Rehabilitation;

Teacher;

Vanity;

\begin{abstract}
After the five basic needs, Man usually seeks power. This quest takes diverse forms namely financial, material, political and social to name just a few. Once it is got, the user may raise problems or difficulties that nobody mainly the holder has ever thought of. Here, it depends on how it is used. Power can be used properly by serving one's fellows. Whether used properly or not, Man's power ends on this earth. In this vein, in order to build a good reputation and or personality of oneself on this earth and after death, one has to use one's power in a good way. This research paper aims at bringing human beings to be aware of the fact that they must account for all their deeds one day or the other, and consequently must think several times before acting or even uttering a single word. If this is known, they must be as modest and honest as possible no matter their power and/or the fields where they operate in order to contribute to the promotion of their community and as such the development of their country. The study has highlighted the failure of Koomson who has misused his power in The Beautiful Ones Are Not Yet Born by Armah on the one hand and the rehabilitation of the man who has always been modest and honest on the other and each of them rewarded accordingly. Otherwise, it has proved that men have always accounted and will always account for their deeds and therefore ripe their fruits accordingly. It has also shown that Armah has been both a novelist and a teacher through the evolution of both characters under study. In order to efficiently explore the topic, I have used the theories of characterization and qualitative.
\end{abstract}

2455-8028 ${ }^{\circ}$ Copyright 2018. The Author. This is an open-access article under the CC BY-SA license (https://creativecommons.org/licenses/by-sa/4.0/) All rights reserved.

\section{Author correspondence:}

Theophile Houndjo,

Faculte des Lettres, Langues, Arts et Communication (FLLAC)

Laboratoire du Groupe de Recherche sur l'Afrique et la Diaspora (GRAD)

Universite d'Abomey-Calavi (Republique du Benin)

Email address: thesympat@yahoo.fr

\section{Introduction}

${ }^{a}$ Universite d'Abomey-Calavi (Republique du Benin) 
It is usually noticed in everyday life as well as through literary works that man seeks power once he has succeeded in satisfying his basic needs. In A Man of The People by Chinua Achebe, the reader can notice how Chief Nanga has accumulated wealth and has also tried to keep power. In Money Galore by Amu Djoleto, Kafu, after his ascension from the position of a teacher to the one of Minister after being elected Member of Parliament, has tried by all means to keep it. Almost like Chief Nanga and Kafu, Koomson has moved from the lower class of railwaymen to the position of "Excellency Joseph Koomson, Minister Plenipotentiary, Member of the Presidential Commission, Hero of Socialist Labor." Armah (1988: 56) the most important thing (concern) here is how power is used. This research paper is based on The Beautyful Ones Are Not Yet Born and aims at showing how precarious human beings' positions are and (therefore) how men should handle them with precautions and care by being modest, humble and honest. This can avoid them being surprised by the negative consequences. "Vanity of vanities! All is vanity" is a biblical verse from Ecclesiastes 1:2) and is the core of the topic that information drawn from Armah's first novel has illustrated all through this paper.

The analysis is centered on Joseph Koomson and the man, two characters in The Beautyful Ones Are Not Yet Born although neither of them has nothing to do with the preaching of The Bible (Gospel). This paper focuses on how the former has reached power and the way he has used it and how the latter has always had a modest life on the one hand and what has happened to each of them in the end on the other hand. The verse is about honesty and humility and their advantages versus boastfulness. This is what I have applied to literature.

The whole novel is mainly the story of these two characters and there is no single chapter where the man is not either dealt with or telling the story including his own. Koomson is described as a very powerful man both financially and politically. The man, in his turn, is described as a poor but honest person. This shows a contrast between the lifestyle of the two characters. Chapter ten reveals the "two extremes" in terms of "the relationship of power and money to the families of the man and Joseph Koomson" (Biodun Ombonoje, Notes, Q/A \& Objective Tests On Ayi Kwei Armah's The Beautyful Ones Are Not Yet Born: 20)

Through this article, I intend to show that no matter how great a person is and the ways through which he has reached this greatness or power, it will come to an end one day or the other. Therefore I would like to bring human beings to know how to run after wealth and power and once they are reached, one must use them appropriately. I have also tried to show that Armah has played the role of both a novelist and teacher.

This paper is divided into three parts. The first part deals with Koomson's life from his school days to his political career; the second part explores the man's life and the third and last part is devoted to Koomson's exile and the man's rehabilitation.

In order to succeed in conducting a deep and convincing analysis, I have used socio-criticism and qualitative methods for this study.

\section{Materials and Methods}

For this study, the materials used are books of different kinds and internet researches. The focused books are The Beautyful Ones Are Not Yet Born and The Holy Bible. Other books, mainly novels such as Money Galore by Amu Djoleto, A Man of The People and Anthills of The Savannah by Chinua Achebe, to name just a few, have been of great importance. Internet researches have also been very useful.

The method used here is socio criticism. As a matter of fact, socio-criticism enables to point out several aspects such as history, society, ideology, and culture when reading a literary text, to paraphrase Pierre Barberis. One must avoid thinking that literary works originate from the vacuum. Although they are fruits or products of writers' imagination, literary works essentially reflect their authors' society. In this framework, the majority of African writers' productions are the mirror of African societies. Among them is the Beautiful Ones Are Not Yet Born which depicts the governance of the majority of post-independence African societies. As far as the resulting design is concerned, I have adopted the qualitative analysis approach. As a matter of fact, this approach is concerned with describing phenomena in a narrative fashion as opposed to the quantitative research approach which describes phenomena numerically. Therefore the quantitative research approach is suitable for this study.

Houndjo, T. (2018). The fulfillment of the biblical statement "vanity of vanities! all is vanity" through the portrayal of two characters in Armah's the beautyful ones are not yet born. International Journal of Linguistics, Literature and Culture, 4(6), 28-41. https://doi.org/10.21744/ijllc.v4n6.339 


\section{Results and Discussions}

This section presents the results of the various analyses I have carried out in the novel. It is divided into three subsections. They are first Koomson's life, then the man's life and last Koomson's forced exile.

\subsection{Koomson's life}

a) Koomson, the Former Pupil, the ordinary citizen, and Minister

Joseph Koomson is not only the protagonist of The Beautyful Ones Are Not Yet Born but also the only one Minister dealt with among the members of Nkrumah's government. Before becoming a minister, Koomson has lived as an ordinary citizen.

We hardly learn about Koomson's parents and relatives. Very little is said about his childhood and teenage. The man just informs the reader that Koomson has been his classmate and has not been intelligent at all. In this framework, he tells the teacher: "Teacher, this Koomson was my own classmate. My classmate, teacher, my classmate." (Armah, 1988: 57). As far as his school performances are concerned, he tells the teacher about Koomson: "He was not very intelligent'...Shit, he was actually stupid". Armah (1988:59) Koomson has not been a brilliant student. Worse still he has been stupid and therefore has produced poor performances. The man has certainly done better, much better than him. After his studies, Koomson has had a job.

One of the most important stages in the life of an honest human being is to work. This prescription can be read about in The Holy Bible and it goes as follows: "... you shall eat the plants of the field in the sweat of your face." (The Holy Bible, Genesis 3: 19). This is one of the things God told Adam and Eve after their sin consisting in eating the forbidden fruit in the Eden Garden. Obi's father confirms this when his son raises the matter of his job application: "'A job is the first thing..." (Chinua Achebe, 1980: 54) Like most human beings, Koomson has worked after his studies. Here too, not much information is given about him. The teacher lets us know that, after his studies, he has become first a railwayman and then a docker and his hands reflect his job. Here, he speaks of the way he behaves towards his colleagues. He says:

Consider your friend Koomson who will make you rich. Remember me.

Koomson we all have known for a long time here. A railway man, then a docker at the harbor. Pulling ropes. Blistered hands, toughened callused hands. A seaman's voice. Big rough man, a man of the docks well-liked by men of the docks. Doing well, the only way we do well here. Not spitting at any countryman, only the fat merchants and their lawyer brothers and Lebanese gangster friends, and that is quite all right here. (Armah, 1988:88-89)

About the same Koomson, he declares:

How can Koomson return to us? What has he got to say to those he used to work with? Will he come down to see the bodies he left behind and not say a word? Can he sit down with men and smoke wee and curse stupid magistrates for jailing men who have harmed no one? He has come here often, but only like a white man or a lawyer now. Swinging time at the Atlantic-Caprice. Young juicy vaginas waiting for him in some hired place paid for by the government. Important people must relax on week-end. [Armah,(Idem), emphasis mine]

The very first above quotation gives us more details of the way people think. They do not seek to know how Koomson works. They just think and conclude the way he should decide himself toward their living conditions, no matter how he proceeds. So, Koomson is thought to connive with bad judges by not being able (or free) to denounce them when they do wrong or when they judge people unfairly. The narrator says of this state of things, talking about Koomson: "Can he sit down with men and smoke wee and curse stupid magistrates for jailing men who have harmed no one? He has come here often, but only like a white man or lawyer now?" (Armah, 1988: Op. cit).

After studying Koomson as a teenager/a schoolboy and as a worker at different places, the next stage is to deal with him as a politician. The reader is not informed about how and when exactly Koomson has entered the political world. Only has the writer presented him in the fourth chapter going to Atlantic-Caprice, a prestigious and famous hotel, with his wife Estella about whom the reader will learn many things when they call at the man's place as well as when the man and his wife pay them a visit too. Let us say a few words about his house (residence) as the starting point of his private life even as a Minister. 
b) Koomson's Dwelling Place

Koomson lives in an area known as the Residential Area. Why this name to the place and who are the people who dwell there?

The man tells the driver who has brought Oyo and himself there that the phrase Residential Area means "a place where people live" (Armah, Ibid.: 143). In the context of The Beautyful Ones Are Not Yet Born, the Residential Area written with capital "R" and capital "A" means not only a place where people live but also a special category of people. This special category of persons includes politicians, big business people, top executives in the civil service and companies and other kinds of Very Important Personalities. The narrator specifies that: "White men, then the old lawyers, and now the bigger Party men and a few civil servants. It was certainly not every fool who could get up and say he wanted to go to that area." (Armah, Ibid.: 141) Koomson lives not only at the Residential Area but also "The Upper Residential Area" and "on the hills beyond the new Esikafo Aba Estates". (Armah, 1988: 140). Koomson is among the highest VIPs who, like in George Orwell's Animal Farm are decreed to be more equal than the others whereas at the beginning of the revolution all animals have been said to be equal. (George Orwell, 1989: 17\&92).

If The Residential Area means the place where people live, this implies that the other places are not qualified for human beings. The issue of a dwelling place is a matter of social classes. Unfortunately, it is the sad reality in most post-independent African countries such as Ghana and Nigeria. Otherwise, other places or many other places than the Residential Area are not qualified for human beings. This Residential Area is the equivalent of Ikoyi within Lagos in No Longer at Ease by Chinua Achebe. Chinua Achebe (1980: 61) it also has its equivalence in Bassa, Capital city of the fictitious country of Kangan described in Anthills of The Savannah. This place is called Government Reserved Area. Chinua Achebe (1988: 107) In "The Upper Residential Area" and "on the hills beyond the new Esikafo Aba Estates" within The Residential Area, what does the Koomsons' flat itself look like?

The Koomsons live in a storeyed-house and as true Africans; they occupy the floor-level and welcome their visitors on the ground level flat. When the man and his wife pay a visit to the Koomsons, it is the Minister who gets down first, informed by Princess, their daughter. As soon as they tell her that they are looking for her father, she answers that daddy's upstairs and then continues minding her own affairs (Armah, Ibid: 144). She behaves the way white children do. White children are not frightened when visitors come to their parents' homes. They just do what they must do. Unlike most African children, they do not come and sit, start looking at visitors' faces or inside their nostrils.

The garden of Koomson's house is good and well taken care of. It is so because first the house is in a special place as already said and then the means are available and last its owner belongs to the upper class. About the garden, the narrator reveals that

the two [the man and Oyo] traversed the big garden in front of the house in total silence. Near the wall on the far side a gardener, very tall and thin, so that he seemed to bend like a reed, was watering an expanse of lush grass. His face was completely covered with a mesh of thin lines cut into the flesh, and he was singing in a voice that was low and calm, except for an occasional sharp cry that rose and separated itself from the main song. (Armah, 1988: $143-144$ )

Koomson has some people who serve him at home. Among them is a servant girl who is about sixteen years old. Armah (1988: 144) He also has a cook who cooks the family's food. He has a steward boy too, Attinga (Armah, Ibid.: 147) Koomson's dwelling place looks like a palace. It is certainly about people like him that one of his country people is talking about when he says that "... Life gets hard when veranda boys are building palaces in a matter of months." (Armah, Ibid.: 93) The man cannot afford all that for lack of means imposing on him a modest life. Salvation will be his. The next subtitle is devoted to the Koomsons' house and his family's standard of living.

\section{c) The Koomsons' Standard of Living and Powers}

Some characters are well at ease and very lucky in their life. Among them, there is the same Koomson and his family. The man has shaken hand with Estella hours before and informs his wife that he can still smell the perfume of Mrs. Koomson. He says: "I shook hands with his wife, and I can smell her still. The hand was wet with the stuff" (Armah, Ibid: 42).

Scornfully, Oyo replies to her husband in the following terms: "'Life treated her well"'. (Armah, Idem). As if this is not enough, Oyo goes far in her will to look like Mrs. Koomson in most ways if not all. It is "a big car", a limousine, which is bringing Estella and Koomson to the Atlantic-Caprice. (Armah, Ibid.: 36). Inside the car, Estella is "complaining of fridges too full to contain anything more and of too much bread already bought. A moment after, Koomson emerges from the car and goes to the seller. At this moment, his wife with her "sharp voice inside the car makes one more sound of impatience then subsides, waiting. (Armah, Ibid.: 37, emphasis mine) The man cannot be in

Houndjo, T. (2018). The fulfillment of the biblical statement "vanity of vanities! all is vanity" through the portrayal of two characters in Armah's the beautyful ones are not yet born. International Journal of Linguistics, Literature and Culture, 4(6), 28-41. https://doi.org/10.21744/ijllc.v4n6.339 
this posture of Koomson's; neither can Oyo in Estella's. Both this incapacity and its reasons will become the key that will open the door of respect, rehabilitation, and dignity to the man contrary to Koomson.

The furniture in the man's house looks like the one that people have used in a remote past in Africa. They do not provide any comfort to their users. Estella is not well at ease, neither is her husband. But while Koomson gives the impression not to mind the kind of seats they are given, while he does not mind their state, their size nor the materials used to make them, Estella in her turn cannot hide her discomfort and unhappiness. About such a situation, the narrator says:

Estella Koomson's handshake was limp, and she withdrew her hand in an insulting hurry and wiggled back in the chair, making in quite plain that she was used to softer, more caressing material beneath and behind her. Koomson himself looked obviously larger than the chair he was occupying. The man when he shook hands was again amazed at the folly softness of the hand. (Armah, Ibid.: 130-131)

The narrator describes Koomson as a very fleshy person unable to sit well in the chair given to him. He is also well perfumed. The narrator informs the reader: "And yet these socialists of Africa, fat, perfumed soft with the ancestral softness of chiefs who had sold their people and are celestially happy with the fruits of the trade. (Armah, Ibid.: 131) In the end, he has stunk the fetid scent of excrement: There lies the irony.

In a country where not everybody can afford only one good meal instead of the three or four per day, a reasonable person cannot imagine that a single man and his wife reach the standard of living and the wealth of the Koomsons. But it is, unfortunately, a reality. The government Koomson is a member of is said to be a socialist one. The most important feature of socialism, whether in real life or in fiction, is the equitable sharing of the country's wealth. It is not the case with Nkrumah's government. Only the minority of the population constituted of political leaders and their close relations enjoy most parts of the country's wealth. Worst still, the embezzled wealth by the politicians like Koomson serves for useless things, considering the poverty the great majority of the people are experiencing, such as the buying of perfumes and diamond rings like the one Estella, the wife of a former railwayman, has worn when going to the men. She is megalomaniac as most people of the social class she belongs to. As an illustration of this megalomania, she objects to drinking the local beer their host has offered them, contrary to her husband, arguing that "this local beer ... do not agree with" her constitution. (Armah, Ibid: 131). She strengthens her position adding that "really, the only good drinks are European drinks" (Armah, Ibid: 132) Hearing these things, her mother's face contract, "oozing shame and hate mixed together." (Armah, Ibid: 134) Oyo's mother has the complex of inferiority. But God's justice, the only irreproachable one, has taught both the old woman and her daughter to behave differently by being humble and courteous. The man's honesty which prevents him from being as opulent and extravagant as some people like Koomson has been rewarding and profitable to him. Oyo has astonishingly but satisfactorily been surprised. How is the Koomsons' flat furnished?

In the house of a minister of post-independent Africa, one can see well equipped and furnished rooms and verandas. Koomson is no exception. When you enter the Koomsons' flat mainly the parlor you can see nice things as revealed by the narrator:

Next, to each ashtray, there were two shiny things; a silver box and a small toy-like pistol. [...]. The light came off the marble tops of the little side tables...

The room itself was only half of a larger space. To the right of the door was what seemed to be the dining room, though whenever he turned round in his seat to look at it, all the man could see was a row of glass-covered shelves and with a multitude of polished dishes and glasses. The sitting room was cut off by a long, high frame, beautifully polished, also with shelves all covered with small, intricate objects that must have come from foreign lands, though of what use they were the man could not decide. To his own left there was one of the new television sets, and then farther on the corner was filled by two large contraptions whose outsides were of highly polished wood. One of them the man recognized as a radio set, though it was amazingly large. The other he found impossible to place. Then there were five deep, soft chairs, all with red cushions, and a carpet on the noiseless floor. There were also the two sofas, on one of which his wife was sitting. (Armah, Ibid.: 146).

Koomson's parlour is so well-furnished that it can be compared with the parlours of the European representatives of the Queen in Africa during colonization and after in contrast with the man's which can be paralleled with the ones of most African middle class during the same periods.

As a matter of fact, Koomson likes comfort. This is illustrated by the way his dining room is well furnished. Although it is well-furnished, the furniture is being renewed by the State Furniture Corporation. Estella Koomson informs the reader that the State Furniture Corporation has come to renew the furniture for them. She tells Oyo that "Joe is like this with the manager" meaning their friendship is 'stainless'. Unfortunately, it is unfavorable to the country and the tax-payers (Armah, Ibid.: 148). He has powers some of which are going to be dealt with a bellow. 
The so-called politician that the women sellers refer to as the Whiteman, Koomson, has real powers that enable him to do things that are not possible for everybody. He is involved in nepotism almost like all Africans in good positions do. He has arranged a scholarship for Regina, his sister - in - law, and former classmate of Oyo's (Armah, Ibid.: 148). Taking advantage of her brother - in - law's position, and also seizing the opportunity of the scholarship arranged for her, Regina becomes too ambitious and greedy. Estella tells Oyo: "She has fallen in love with a Jaguar, and she's going to kill herself if she can't have it. She wants us to get her the foreign exchange for it. "(Armah, Ibid.: 149) It is not only Koomson who is a megalomaniac but also people around him like his wife and his sister-in-law. It is in this vein that one of the boats bought by Koomson bears the name of his daughter: "PRINCESS" (Armah, Ibid.: 152). This way of doing things is comparable with the way Western powers connive with African leaders to siphon African resources of all sorts. Koomson will be dethroned and the man rehabilitated in his dignity. Here below is more information about the man

\subsection{The Man's Life}

\section{a) The Man's Dwelling Place}

In the $20^{\text {th }}$ century Africa, people who are not deeply involved in politics or in business, usually have a low standard of living. Fiction reflects this reality. The man is no exception to this rule. His family's standard of living is described taking into account three aspects. The first aspect is the description of his family's dwelling place including the house itself, its doors, the bathing room and windows, the furniture, the electronic household appliances. The second aspect is the way they dress and what they wear and last is how they feed themselves.

One of the five basic needs in the life of human beings is housing. Any human being is entitled to a decent house or shelter. Unfortunately, this is not always the case with everybody mainly in developing countries. In Ghana under N'Krumah's regime as described by Armah in The Beautyful Ones Are Not Yet Born, many people are poor, very poor. As a consequence, they don't live in decent houses. Two of these people are the man and Kwesi Anan, the boatman. The latter lives in "a converted lavatory" where there is "no place to take the visitors" because it is "not a room at all." (Armah, Ibid.: 150) The narrator describes the same room as a "low house that looked like some long thing flattened against the earth" (Armah, Ibid.: 172). What do the man's house and its outbuildings look like?

The place where the man and his family life is almost insane or unclean mainly the bathroom. In front of the flat, there is a puddle and it is widening. There are also "four little stairs on to the veranda." The flat has a hall, at least a bedroom, a kitchen (Armah, Ibid: 41) and a bathroom. It is not incorporated into the building, so one has to go out before taking his bath. The door of the bathroom is rotten at the bottom and therefore smells "of dead wood filled" the man's "nostrils and caressed the cavity of his mouth." (Armah, Ibid: 101) The bathroom is a public one, so it is not for the man and his family alone. Other people from several households use or share it with the men. Consequently, the sanitation of the place is questionable. Talking of the bathroom, the narrator says that "the hole leading the water out was again partly blocked with everybody's sponge strands, so that the scum formed a kind of bar just before the hole and the water underneath went out very slowly, a little at a time, and there was a lot of it covering the floor when the shower had been running even a little while" (Armah, Ibid.: 102) This proves that the place is dirty with bad hygienic conditions. This place looks almost like Akobi's bathroom as described by the narrator. (Amma Darko; 1995: 12) The man wears either "car-tire sandals" or "rubber sandals" (Armah, Ibid.: 101-102).

\section{b) The Man and his family's Standard of Living}

In Ghana under Nkrumah as described in the focused novel, poor people like the man usually eat gari, beans, kenkey, cassava, and dough to name only these; so do the members of his family. For instance, the man cannot afford to buy and eat $f u f u$ and meat because it is expensive. At work, he can afford

gari and beans with palm oil, and in spite of the worrying thought that it is not called concrete for anything, the man begins to enjoy it. A poor man must learn to suffer from his bottom also. He takes his pan and moves under the shade of a nim tree, ... (Armah, Ibid.: 110)

The above quotation illustrates the pitiful situation the man is going through. He eats gari and beans for lunch and under a tree, which is unthinkable of Koomson who used to be a lazy pupil. "But now as a party man, a minister, he eats food in air-conditioned rooms of hotels and restaurants with spoons, forks, and knives the same way as the old lawyers. This is how life goes with politicians like Koomson. The other workers who are spending the break time at the same place as the man reveal what follows:

Houndjo, T. (2018). The fulfillment of the biblical statement "vanity of vanities! all is vanity" through the portrayal of two characters in Armah's the beautyful ones are not yet born. International Journal of Linguistics, Literature and Culture, 4(6), 28-41. https://doi.org/10.21744/ijllc.v4n6.339 
Between sighs and bits of bitter laughter, phrases that are too familiar pepper the air." He is only a small boy ...'Yes, it's the CPP that has been so profitable for him... Two cars now' ... 'No, you're way behind. Three. The latest is a white Mercedes 220 Super" 'You will think I am lying, but he was my classmate, and now look at me' 'Ah, life is like that', 'Ei, and girls!' 'Running to fill his cars. Trips to the star for weekends in Accra. (Armah, Ibid.: 110)

The above quotation displays the big, wide and deep gap that can be noticed between the masses' living conditions and the politicians'. This situation can be explained by the opulence on the one hand and scarcity or poverty on the other. The omniscient narrator witnesses the man and his family's lunchtime and reports:

The children were already eating their lunch, round, single sliced pieces of kenkey " with each a smear of sardine, stew on it. The man took his plate from on top of a little stool, where his wife had placed it.

'I would have brought it to you myself, out there,' she said.

'It doesn't matter,' he said. 'I wanted to eat with you.'

'I have had mine,' she said.

"I don't believe you, the man said. But the woman only smiled. The man insisted. 'At least you can keep me company.'

The woman began to eat with her husband. The children had moved out of the kitchen itself when their father entered, and sat just outside the door, keeping their eyes away from their parents within. The man could see how little the stew was with which they were trying to eat their kenkey. But it had always been like that. Once or twice he had impulsively given up his food so they could have more meat. But if he really wanted to give them the food they needed, they would certainly have to go naked, or he would have to go hungry. The kenkey inside his mouth tasted dry, like chaff. He rose before the feeling of hunger had left him, and his wife sat there saying nothing, Just staring after him.. (Armah, Ibid.: 119-120; emphasis mine)

This shows clearly that poverty prevails in the man's household. This would never happen in a politician's family. The man's poverty is not only illustrated by the flat where he lives and the foods they eat ... but also the furniture and the electric appliances. The man does not have any fridge to refresh and freeze their foods and drinks and other usable goods that can be kept cold. In order to welcome Estella and Joseph Koomson, the man has been obliged to freeze the beer he has bought in his friend Bentil's fridge. For this, he informs his wife Oyo. "I want to take the beer over and put in Bentil's fridge"... (Armah, ibid.: 120).

In the twentieth century, the second half of which the focused novel was published, it was ... common fact that a single family owns at least a TV set mainly families whose heads are wage or salary earners. Although the situation is described in an imaginary work, one must recognize that a novel does not evolve from a vacuum. Concretely, the man does not have any TV set for the entertainment of his family. This situation is revealed through the astonishment or admiration shown by the man's daughter when she sees a TV set in a house while they are going to their grandmother's house. The narrator reports:

Ei look! There is a television in that house. The middle one? She turned in a full circle, swinging the bag.

"Television is so beautiful!

"B...o...s...s!' the boy spelled.

Ask Father, the girl said. Papa, is television not very beautiful?

You see I' shouted the girl in triumph. The boy bared his teeth and pushed his head out menacingly toward the girl, but she only

laughed. The man's neck was beginning to hurt from the weight of his little daughter. (Armah, Ibid.: 121-122)

Another illustration of the man's poverty is the fact that he cannot provide his wife and children with the minimum they need as far as their clothing and body care are concerned. For instance, Ayivi does not wear any shoes while being brought to his grandmother's on the occasion of the visit of Estella and Joseph Koomson to his parents. The narrator reports the old woman's words here:

My poor husband!' said the old woman, over and over again. You have no shoes to wear, so your poor little feet get torn to pieces. $\mathrm{Ei}$, my husband, you have nobody, nobody to buy you shoes, so your little toes will all be destroyed. She went close up to the boy and peered down at his feet, looking for the one with the cut on it.

"Where is the wound, my husband? Where is it ? You must know you have nobody, you are an orphan. You mustn't run around, like people who have men behind them, to buy them shoes. My poor husband! (Armah, Ibid.: 123, emphasis mine).

The man's mother-in-law's contempt for him is so deep that even in his presence she goes far to compare his son, her grandson, with an orphan.

Oyo herself lacks the minimum from her husband to take care of her as the wife of a salary earner. She is obliged to comb her hair with a hot and oily comb in order to have it presentable for lack of a wig which is necessary, according to her. She tells her husband: "If I had a wig, there would be no trouble. (Armah, Ibid.: 129) Estella would go to the best furnished and equipped hairdresser's for care, contrary to Oyo. 
Taking into account the situation like the one just described, Oyo's mother challenges her son - in - law in the following term: "Ah yes, the suffering daughter of mine, what does she say?" As she seems not to have noticed the necessary chock she expects to cause in the man, she says more bitterly: "Is that what you say", she asked at slow length. "Do you really say my daughter is alive? And is she also well?" The man restrained a smile. "Ah, then we thank the Lord!" (Armah, Ibid.: 123) When the old woman brings her grandchildren back to their parents, she reacts to her daughter's concern to give food to the children in the following terms: "I fed them!" The old woman went on. "I fed them and they ate it all, so hungry they have been all their young lives. You really must not let them go hungry like that." (Armah, Ibid.:130). The man's mother-in-law is determined to tell him that he is one of the nonentities (almost Good-for-nothing), the equivalent of Efulefu with the Ibo people which means "a worthless man". (Chinua Achebe, 1975: 157) She utters the following sentences about her son-in-law while her daughter and the latter are with her.

\footnotetext{
Aaaah, Koomson has done well, we must say it. He has done well for himself, and for his family too ...

"I must say that there are men somewhere in Ghana who at least know how to take good care of their own... "... "People who can do manly things, and take the burdens of others too. (Armah, 1988: 139).
}

The man's mother-in-law is determined to humiliate him but unfortunately, she fails because her daughter Oyo does not take this into consideration to debase her husband. At times, she even openly shows disagreement with her mother's displeasure by not reacting or by disagreeing. She says: "it is enough mummy." For instance, after the departure of Estella and Joseph Koomson, Oyo's mother continues to challenge the man. She tells her mother politely: "it is late" meaning she must keep quiet and leave them. (Armah, Ibid.: 139). Why is the man so socially disabled?

\section{c) The Man's Aversion for Corruption}

Since her husband seems not to be ready to take the way to this wealth that can enable him to provide his family with the material goods and money as Koomson does, his wife shows him the way through the following dialogue after the man has informed her that he has rejected bribe from the timber contractor:

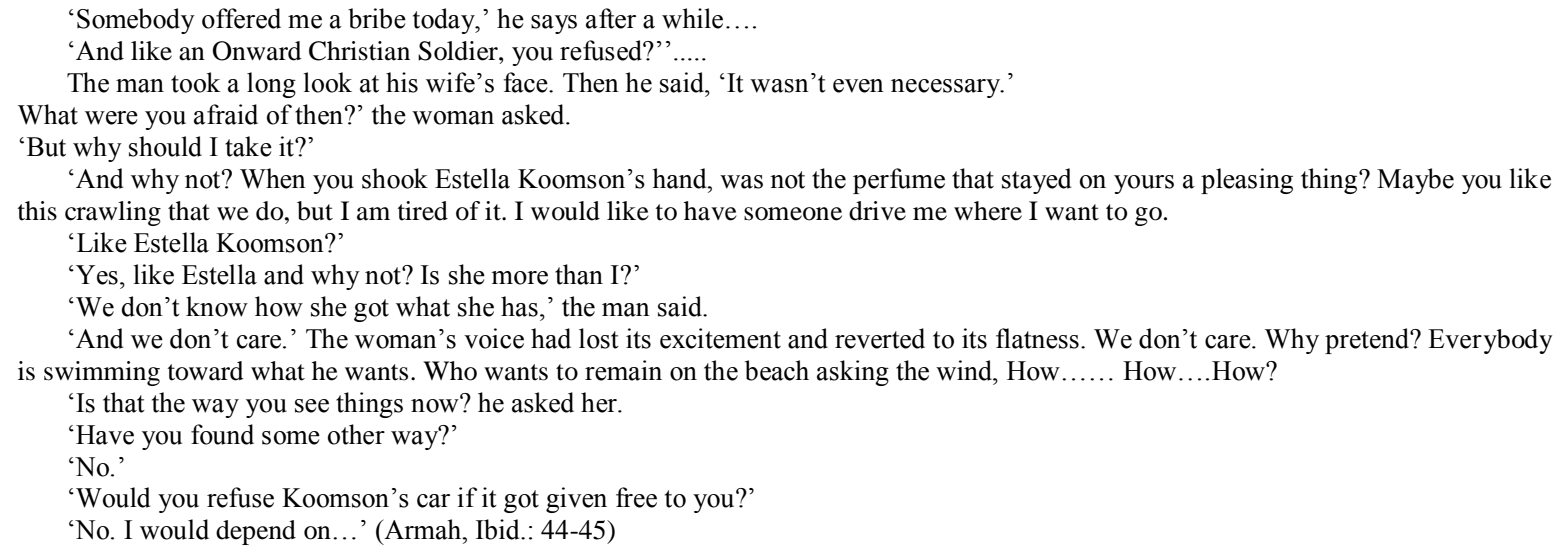

For Oyo, it is the end which justifies the means. In other words, the man must take a bribe in order to be able to take care of his loved ones conveniently if he does not find other ways to do it. Her concern is to look like Estella no matter the ways and their consequences. She will be aware of the fact that she has always been wrong in this field.

Because the man cautiously refuses to be involved in the boat buying and management business, his wife scornfully refers to him as a chichidodo and in his presence. She tells him: "you are the chichidodo itself" (Armah, Ibid.: 44). Her husband is intrigued and tries to know the meaning of the word chichidodo, in her turn, without beating about the bush, she explains it to him. She says: "Ah, you know the chichidodo is a bird. The chichidodo hates excrement with all its soul. But the chichidodo only feeds on maggots, and you know the maggots grow best inside the lavatory. This is the chichidodo". The woman was smiling (Armah, Ibid.: 45).

Through the explanation, she gives of chichidodo one can guess that the woman is telling her husband that he is not only a profiteer but also a hypocritical person. She cannot find a more sophisticated and cunny way or words to debase him. The narrator says that she "was smiling" while explaining it to her husband. This behavior of Oyo's reported by the omniscient narrator proves that the carelessness of Oyo for her husband has reached its climax due to her disappointment from him because of the latter's lack of interest for the boat business I have already dealt with.

Houndjo, T. (2018). The fulfillment of the biblical statement "vanity of vanities! all is vanity" through the portrayal of two characters in Armah's the beautyful ones are not yet born. International Journal of Linguistics, Literature and Culture, 4(6), 28-41. https://doi.org/10.21744/ijllc.v4n6.339 
As if this offence and contempt were not enough, one evening, after serving food to her husband, Oyo goes far by telling him, mockingly, of course, that "that fish came straight from Koomson's boat" (Armah, Ibid.: 153). Shocked as well as disappointed, the man calmly tells his wife: "Please don't cook any more fish for me" (Idem). He feels alone. The omniscient narrator reports that "the terrible feeling of loneliness again came over him in his own home, and he walked out with a desperation that was no less deep for all its suddenness, gripping through the might for the only human hand that could touch his and not make him feel a stranger to life." (Armah, Idem)

Fortunately, the time has taught her the lesson of life and she has changed her mind even if it is late but it is never too late to change from bad to good or simply "better late than never". After the coup, she tells the man that she is proud of him. The narrator reports: "He went back into the hall and stood quietly beside Oyo. She held his hand in a light grasp. Then, in a voice that sounded as if she was stifling, she whispered, 'I am glad you never became like him.' (Armah, Ibid.: 165) Nobody could believe that Oyo could say these words to her husband since together with her mother they have always laughed at him because he has refused to become or behave like Koomson. So is life, even if fictitious works.

Last but not least, even the worst illustration of the man's poverty is the place and the way his children sleep. One night, the omniscient narrator can see them sleeping: "Adoley and Ayivi were sleeping in the hall, entangled like some strange kind of Siamese twins in the same chair". (Armah, Ibid.: 160) Contrary to the man's "Siamese twins' sleeping in the hall, Koomson's loved ones will never behave this way or sleep in this position. They might sleep in a large framed sofa or in their separate beds in an appropriate bedroom. The Koomsons' visit to the man enables us to have an idea of both the kind of furniture the man has but also the Koomsons' standard of living.

All that has happened in Koomson's country where very few individuals are more important than the masses although the latter represents, nevertheless, millions of people, is astonishing in the normal course of things; a country where very few people, mainly party men, consider the Commercial Bank as their private property, things usually end in chaos. (Armah, Ibid.: 136) As a matter of fact, a military coup takes place and Nkrumah's government is overthrown. The messenger answers the man that it is the army men and policemen who have seized power. (Armah, Ibid. 157) What is the aftermath of the military coup in relation with Koomson?

\title{
3.3 The Night has Fallen at Midday: Koomson's Exile
}

\section{a) Koomson at the Man's}

It is a common fact that after a military coup some big politicians are killed, others are arrested and some others run away. The first noticeable thing that happens after the military coup is that "all big Party men were being arrested and placed in something called protective custody-already a new name for old imprisonment without trial" (Armah, Ibid.: 157). As it usually happens in a situation like the one during which people are wanted by the police, the former try to hide or run away. In this framework, Koomson is hiding at the man's house, fearing to be arrested. The narrator describes him here in his hideout:

\begin{abstract}
Koomson was sitting on the bed, just behind the screen. He looked like a man afraid that the utterance of a single word would be the end of him. He was in a suit of dark woolen material with a shirt whose brilliant whiteness had in the sudden light a tinge of blue, and a black bow tie. On his nose small points of perspiration stood, looking as if they were about to increase in size and fall every next moment. But they did not fall. Koomson set rigid for a few moments, like a person knowing it was a matter of the greatest importance for him to avoid making any motion at all. Slowly, as if he were trying to do it without attracting the attention of invisible watchers, he raised his staring eyes in the direction of the light above, then looked imploringly at the man. (Armah, Ibid.: 161, emphasis mine)
\end{abstract}

This quotation shows that "Vanity of vanities! All is vanities". For, Koomson can't be imagined being frightened by an arrest by the police who have been under his orders until very recently to the point of "imploring at the man". Although he is now in a place that can be considered as safe, Koomson is still afraid. He tells the man: "they will kill me". (Armah, Ibid.: 163) Therefore he wishes he could disappear. The narrator says of his state of mind: "Koomson sitting up on the bed, his body drawn up as if his greatest remaining wish was to grow smaller, to disappear if that would be possible." (Armah, Idem) Koomson is hungry and must eat. He eats in conditions less good than the one of a beggar: "Koomson ate in darkness. It was again hard to see since Koomson did not want the door open... Now the man could leave him." (Armah, Ibid.: 165) .

Koomson is always well perfumed as an omnipotent minister. But when he is hiding in the man's bedroom, he smells as the heat, the darkness and his clothes favor such a situation, an unbearable smell. The narrator says: 
It was quite dark inside. The smell was something the man had not at all expected. It was overpowering as if come [sic] corrosive gas, already half liquid had filled the whole room, irritating not only the nostrils but also the inside, of eyes, ears, mouth, throat. It was difficult at first to tell where Koomson was in the darkness, so the man reached for the wall switched and turned on the light. (Armah, Ibid.: 161)

Who could believe Koomson in such a situation trickier than a mess? Nobody until the coup takes place. This is the vivid evidence that earthly power stops on this earth.

\section{b) Koomson, From the Man's Place Abroad}

After this unthinkable episode, Koomson must leave the man's place for another safer than the man's: to go abroad. But the next place, safer than the man's before going abroad is, according to Koomson himself, Kwesi Anan's that I have already described as a place not qualified for a human being. It has been very difficult for Koomson to leave the man's place to the boatman's. He has to go through a latrine hole, something which is undoubtedly very difficult for ordinary people even latrine men, worse still a minister, a fat and usually perfumed minister with his soft hand. Here, the narrator describes this unthinkable but true event in Koomson's life:

\footnotetext{
'We'll have to go through the latrine man's hole,' the man said. Koomson did not answer. 'You go first,' the man said. He felt he had to add something by way of explanation, so he added, 'If they come...'

'You can't go that way,' he said softly. 'You'll get stuck.' Koomson was hesitating. He did not seem to think there was anything else he could do now. 'Headfirst,' the man said. 'That is the only way.'

The man saw the party man frantically kick his legs. Quickly he grasped the legs and pulled with all his force. Koomson's head hit the edge of the hole as he came out. (Armah, 1988: 167-168). (emphasis mine)
}

The above quotation is the vivid illustration of the fact that Koomson has already started experiencing life in Hell before his death. It is the way he has been able to move from the man's dark bedroom to outside and take the way to the boatman's place. This episode corresponds to the denouement of the novel.

Fortunately, he will stay there for a while just to bargain his flight from Accra, Ghana, to Abidjan in Côte-d'Ivoire. Koomson has become so small to beg his own servant. The man confesses such a situation saying that "it would be up to Koomson himself to frame the words to beg his servant", Kwesi Anan. In this vein, Koomson begs him to help him as the narrator reports it here "'if you can help me', Koomson said to the boatman, "half the fish boat will be yours" (Armah, Ibid.: 174)

The help here is to enable him to join the fishing harbor in order to board a boat or a canoe to join Abidjan. Involved in corruption from his toes to his highest hair while running the country, Koomson quickly agrees to bribe the watchman at the harbor gate by giving him one hundred cedis before entering the fishing harbor (Armah, Ibid.: 175176). Once inside the harbor, the man and Koomson "climb into the boat and once inside it" [...] "the boat moved out slowly, first into the center of the dock space, then, gathering speed, it slid past the long arm of cement forming the outside breakwater and left the still, black water weighing it behind." (Armah, Idem). Unexpectedly, a new page is opened in his own or private life and in the life of his country too. Koomson is on his last way to exile. The narrator reveals here how Koomson and the man are saying farewell to each other, the man going back home and Koomson to Abidjan:

'You are going, then,' said Koomson, coming forward to the man.

'Yes?'

The Party man took his hand. 'Thank you?' The man heard the words, but he felt nothing for Koomson.

'We shall meet again?' Koomson said.

To the man the words sounded funny and childish, but, as if he were not himself but someone completely different, he heard himself repeating, 'We shall meet again.' (Armah, Ibid.: 178)

This is the way Koomson's life in Ghana has come to an end. Who could believe it? Nobody could from the omnipotent and very wealthy Minister in his tenure of office. This is the reason why we have introduced the quotation with the adverb "unexpectedly".

Another protagonist of a political novel set in West Africa and that has had the same end as Koomson is Chief Nanga. Chief Nanga has been several times a member of the government of an African fictitious country whose capital

Houndjo, T. (2018). The fulfillment of the biblical statement "vanity of vanities! all is vanity" through the portrayal of two characters in Armah's the beautyful ones are not yet born. International Journal of Linguistics, Literature and Culture, 4(6), 28-41. https://doi.org/10.21744/ijllc.v4n6.339 
city is Bori. Almost like Koomson, he has been omnipotent and wealthy; he has accumulated wealth but has had almost the same end as Koomson. About his end, the narrator says that they "were told Nanga was arrested trying to escape by canoe dressed like a fisherman'. (Chinua Achebe, 1975: 147) Joseph Koomson has not been arrested but Chief Nanga has. The similarity here is the fact that in both cases nobody could imagine such an end for neither of them.

Another dictator, corrupt and pitiless political leader described in a novel set in Ghana is Kafu. Nevertheless, his powers do not prevent him from being killed, unwillingly, by his own watchman who is trying to save him from his creditors who are tormenting him physically. (Djoleto, 1975: 181)

\section{Conclusion}

This article has so far dealt with several points. The first is the disadvantages in relation to embezzlement of public properties of any kind and the abuse of power. As a bad deed it is punished. An illustration of this is the failure of Koomson whose government has been overthrown and he himself been compelled to go to exile through humiliating ways. His (Koomson's) whole life proves that "vanity of vanities! All is vanity".

The second point dealt with in this article is the importance of humility, modesty, and honesty in all fields. As a matter of fact, the man has always been morally and professionally honest. Therefore, he has been rehabilitated in the end accordingly. This situation has compelled Oyo to acknowledge that she has always been wrong by laughing at her husband all the time. She proves this congratulating him: "I am glad you never became like him [Koomson]" (Armah, Ibid: 165) "Vanity of vanities! All is vanity ..."

Considering the way both Koomson and the man have been rewarded, I can say that all human beings must keep in mind that our deeds are like a shade that goes along with us every day and everywhere. Both the deserved praise the man has received from his wife and the pitiful end of Koomson are an acknowledgement of the biblical verse which stipulates that: "the first will be the last and the last will be the first" (The Holy Bible Matthew 20: 16) It is also an illustration of Anthea Bell's thought put in the introduction to Silas Marner by George Eliot which goes the following way: “... We generally get what we deserve and it is not worth trying to avoid the results of our action." (George Eliot, 1978: xv)

This article has also highlighted the fact that a writer can be both a novelist and teacher. What Armah is.

Armah, through the focused novel, teaches the reader that, no matter who you are, there are more powerful than you and that earthly power always comes to an end one day or the other. In his novel under study, Armah proves to be a great teacher. He clearly teaches African peoples in general and African political leaders in particular that by mismanaging their respective countries' affairs, the countries will remain underdeveloped and they must account for that. In this vein, the omnipotent Koomson and the whole government have been overthrown and he has, luckily, been able to go to exile despite his titles. "Vanity of vanities! All is vanity".

Consequently, novelists sometimes if not often play the role of teachers because most readers want them to show them, through their narrators, either what is bad or good or both. Achebe has opined about this idea. Through his article "The Novelist as Teacher", Chinua Achebe lets us know that some of his readers want him to play the role of a teacher through his writings. For instance, I. Buba Yero Mafindi from the North of Nigeria wrote this to Achebe: Your novels serve as advice to us young. I trust that you will continue to produce as many of this type of books." [G.D. Killam (ed.), African Writers on African Writings: 2]

When writing about seasons in Africa, an African pupil replaced harmattan by winter. For Achebe, this is a blasphemy "that must be purged. He, therefore, assigned himself the following task: "I think it is part of my business as a writer to teach that boy that there is nothing disgraceful about the African weather, ..." (G. D. Killam, Ibid.: 3)

I have no competing interest with anybody. The study has been financed by myself. I have also approved the final article.

Conflict of interest statement and funding sources

The author declared that he has no competing interest. The study was financed by personal funding.

Statement of authorship

The author has a responsibility for the conception and design of the study. The author has approved the final article. 
Acknowledgments

I sincerely thank Dr. Innocent Koutchade, associate professor at Abomey-Calavi University and Nicolas Gbegnavo, a doctoral student at the same university for their precious contributions through suggestions after having read the first draft.

Houndjo, T. (2018). The fulfillment of the biblical statement "vanity of vanities! all is vanity" through the portrayal of two characters in Armah's the beautyful ones are not yet born. International Journal of Linguistics, Literature and Culture, 4(6), 28-41. https://doi.org/10.21744/ijllc.v4n6.339 


\section{References}

Abrams, M. H., \& Harpham, G. G. (2005). A glossary of Literary Terms. Wadsworth Cengage Learning. 25 Thomson ${ }^{c e}$ s place, Boston, USA. MA02210, USA.

Achebe, C. (1989). No Longer At Ease. London. Heinemann.

Achebe, C. (2012). Hopes and impediments: Selected essays. Penguin.

Akyeampong, E. K. (2008). Themes in West Africa's History. African Diaspora Archaeology Newsletter, $12(2), 14$.

Amoussou, C. Y. (2011). Characterisation, Focalisation and Discourse in Ngũgĩ wa Thiong'o's Novels: A Functional Structuralist Approach.' Unpublished Ph. D-Dissertation, UAC.

Armah, A. K. (1988). The beautyful ones are not yet born. Heinemann.

Barkindo, B., Omolewa, M. and Maduakor, E. N. (2014). Africa and the Wider World: West and North Africa Since 1800 Tomes 1, 2 \&3. Learn Africa Plc. Ikeja, lagos.

Djoleto, S. A. A. (1975). Money galore (Vol. 161). Heinemann Educational Books.

Dossou-Yovo, N. (1992). Individu et société dans le roman négro-africain d'expression anglaise de 1939 à 1986 (Doctoral dissertation, Nancy 2).

Eliot, G. (2003). Silas marner. Penguin UK.

Fraser, R. (1980). The novels of Ayi Kwei Armah: A study in polemical fiction. London: Heinemann.

Houessou-Adin, T. (2011). Prolegomena to Critical Literary Analysis and Text Explication. HotepBooks, First Edition, Cotonou-Bénin

Karanja, W. (2003). Corruption scandal. World Press Review, 50(10), 28-28.

Killam, G. D. (Ed.). (1984). The writing of east and central Africa. East African Publishers.

Klages, M. (2012). Key terms in literary theory. Bloomsbury Publishing.

Klages, M. (2012). Key terms in literary theory. Bloomsbury Publishing.

Kounnou, A. J. (2013). Political Chaos and Corruption as the Major Causes of Africa's Underdevelopment Through Achebe's A Man of the People and Soyinka's The Interpreters, Mémoire de Maîtrise, Université d'Abomey-Calavi, Bénin.

Martin, M. P. and O’Meara, P. (eds). (1995). Africa, Third Edition. Indiana University Press. Bloomington and Indianapolis; James Currey. London.

Maxwell, O. (1970). "Uses and Abuses of Political Power: A case study of Continuity and Change in the Politics of Ghana" in Chicago University Press.

Ngugi, W. T. (1981). Return to the Roots: National Languages as the Basis of a Kenyan National Literature and Culture. Writers in Politics: Essays.

Olaniyan, T. and Quayson, A. (2013). African Literature: An Anthology of Criticism and Theory. Blackwell Publishing Ltd. Malden, Oxford, Carlton, Victoria.

Orwell, G. (1989). Animal Farm. Ikeja, Lagos. Longman Group Limited.

The British \& foreign Bible Society. (1967). The Bible, Revised Standard Version, Illustrated. Collins Clear-Type Press.

Tiffin, B. A. G. G. H. (2007). Postcolonial Studies: The key Concepts. New York: Routedge, 99-100.

Wolfreys, J. (2010). Literature in Theory. New York. 


\section{Biography of Author}

Dr. Théophile Houndjo was born in 1968 in his native country, the Republic of Benin.
He defended his doctoral dissertation in African literature in English in February 2014.
But before that, he had started lecturing in African studies, literature, and civilization, in
the Department of English at Abomey-Calavi University, Republic of Benin which he
has kept on doing so far.
Email: thesympat@yahoo.fr

Houndjo, T. (2018). The fulfillment of the biblical statement "vanity of vanities! all is vanity" through the portrayal of two characters in Armah's the beautyful ones are not yet born. International Journal of Linguistics, Literature and Culture, 4(6), 28-41. https://doi.org/10.21744/ijllc.v4n6.339 